\title{
Reforming
}

\section{health-care management in Latin America}

\author{
Ana Sojo \\ Social Affairs Officer, \\ ECLAC \\ asojo@eclac.cl
}

Following a conceptual analysis of the term "quasi-market", this article will look at four national efforts to reform healthcare management in what can be regarded, in respect of the degree of solidarity and universality applied, as three different health-care models. The changes in Chile are a continuation of the country's previous reform, which went further than any other in the region in undermining the solidarity and universality of the health-care model. The conclusion is that it would be beneficial to consolidate purely managerial aspects so that progress can be made with the use of administered prices, relevant information on the quality and cost of care can be produced, and efficiency and effectiveness criteria can be applied to clinical services. In Argentina and Colombia, while there are large differences between the two, the changes that have been made are part of a reform process aimed at encouraging competition while upholding the principles of solidarity and universality. Because change has mainly centred on the financing model, management has had a subordinate place since the outset. In the case of Colombia, the article highlights the excessive complexities of hospital financing, which have combined with regulatory shortcomings to inhibit management change. In the case of Argentina, where hospitals are excessively large, it describes the wide range of hospital management reforms that have resulted from past decentralization, the degree to which management is independent of fiscal discipline and the different ideas that exist of the part played by hospitals in referral systems. In the case of Costa Rica, where health care is primarily public and based on principles of solidarity and universality, the article looks at the creation of internal health markets that resulted from the introduction of a new performance-related organizational and financing model in the Costa Rican Social Security Fund; it notes that the management contracts used have interesting features as regards organization and information and the shaping of a health-care system, but that they are excessively complex and involve high transaction costs, and it analyses the difficulties involved in introducing real provider decentralization and creating performance incentives. 


\section{I}

\section{Introduction}

Health quasi-markets promote competition among providers and/or insurers, but differ from conventional markets in certain respects. On the demand side, buying power is manifested in the form of a budget agreed with the public-sector purchasing organization. Consumers are represented by agents, i.e., by a buying organization whose character is determined by the way the quasi-market is organized and by the ground rules of the insurance system. Prices are negotiated or administered within a budgetary framework. Supply, meanwhile, can embrace various forms of ownership -State, municipal, trusts, consortia and non-profitmaking organizations- which may be subject to different financing rules (Bartlett and Le Grand, 1993, pp. 23 and 24).

Competition can be introduced at different levels, by altering the public-private mix through the extension of private-sector involvement, or by changing the charters of public-sector provider institutions to give them greater independence in the way they use their resources in a competitive environment governed by the regulatory framework of a contract, or allowing them to operate under private law. Different mechanisms can promote competition among providers, such as freedom of choice in the referral system or among health-care professionals, or competition for budgets among hospitals.

Quasi-markets conform to two rationales. ${ }^{1}$ Where public-sector providers are concerned, the aim is to introduce competition in the public sphere by separating functions, thereby improving efficiency and quality. Where a public-private mix is concerned (when health is regarded as a public good because its positive externalities are greater than the individual benefits, or as a merit good that actualizes a social right), the aim is to cater to demand, irrespective of providers' prices and individuals' state of health and ability to pay, by applying ground rules for insurance, financing and provision that establish conditions of solidarity by means of cross-subsidies among income strata or risk or age groups, or by means of subsidies to specific groups. In both cases, financing is linked to productivity, coverage, yield and success in meeting targets.

In Latin America and the Caribbean, management reforms now being implemented represent moves towards the creation of quasi-markets. These reforms have been applied to health-care models that are dissimilar in terms of their guiding principles, the responsibilities of the public and private sectors, service and population coverage, financing and insurance models, and regulation. In many cases, the legal basis for the mechanisms introduced is flimsy, pricing plays a strictly theoretical role, and consolidation would require changes in employment practices that would be politically very complex to achieve. Despite everything, the quasi-markets that are in prospect offer a promising route towards the goals of greater efficiency, accountability, responsiveness and choice, without adverse consequences for equity. This article analyses the management reforms implemented in Chile, Colombia, Argentina and Costa Rica, considering the progress they have brought about and the obstacles that have arisen in practice.

The author wishes to thank Jairo Restrepo and the research team at the Economic Research Centre (CIE) of the University of Antioquia for their views on a previous version of this article and their comments on the concept of health and the Colombian reforms, and Oscar Altimir for his remarks on this version.

${ }^{1}$ In conversation, Rebeca Grynspan distinguished two particular rationales that have usually been implicitly assumed in discussions of the subject. 


\section{II}

\section{Chile: adjusting management when solidarity and universality have been undermined}

The Chilean reform of the 1980 s, which was made possible by an authoritarian context, was unprecedentedly radical. It stands in complete contrast to the British experience under the Conservative Governments of Thatcher and Major. In Britain, the Conservatives mounted a radical challenge to the financing methods, scope of provision and publicprivate mix of the National Health Service (NHS). Following a variety of political developments that impeded radical change, the NHS was reformed, paradoxically, by increasing the separation of functions with a view to promoting competition. ${ }^{2}$

Compulsory insurance is a feature of public or national social insurance systems that seek to achieve stable risk differentiation and may aim at redistribution and social solidarity, with a variety of public-private mixes. The Chilean health-care system, therefore, is unique in the world. Under its dual logic, workers have to pay compulsory subscriptions, entirely at their own cost, which entitle them to membership of the public health service through the National Health Fund (Fonasa), whose distribution rationale favours solidarity, or the private health insurance institutions (Isapres), which operate on an individual risk-associated private insurance basis.

Fonasa gives access to public provision under the so-called institutional system or to private provision of choice, subject to co-payments of various kinds, and is also funded by other contributions deriving from the public budget. Isapres, contrary to the logic natural to a compulsory insurance scheme, provide individual insurance plans that are renewable each year and incorporate risk selection, as price and coverage are adjusted for the age, health risk and sex of the insured. They cover about $30 \%$ of the population, and their prices have risen by far more than those of other sectors

\footnotetext{
${ }^{2}$ Out-patient care by general practitioners was already provided under contract; then hospitals were allowed to operate independently under NHS contracts, which led to providers being grouped into trusts. On the reforms to the British system, see Ferlie and others (1996), Walsh (1995), Bach (1999) and Winchester and Bach (1999). For a detailed discussion of the political process, see also Porter (1999, pp. 236-259).
}

of the economy. ${ }^{3}$ The public-sector scheme, which has no barriers to entry, covers the lower-income and higher-risk populations, and provides blanket reinsurance for the system.

The measures taken so far to improve management in the Chilean public health-care sector have been in the nature of an adjustment, seeking to raise the efficiency and effectiveness of the public subsystem without altering the dual design of the public-private mix introduced in the 1980s.

\section{Organizational aspects and contractual characteristics $^{4}$}

Management contracts between the central level and health services were introduced in 1995, with resources to be allocated and transferred to provider organizations under an annual service provision agreement establishing performance indicators. These organizations were encouraged in turn to enter into contracts with the public hospitals and municipalities to which they were linked. ${ }^{5}$

These agreements have gradually helped to organize relations between the health services and the centre, which were traditionally governed by formal and informal bilateral agreements between specific organizations, resulting in a lack of coordination, duplication and overlap, and in substantial resources being devoted to lobbying. With the Ministry of Health retaining provision functions, something that has been identified as a major obstacle to restructuring the health sector, ${ }^{6}$ agreements were also structured and evaluated

\footnotetext{
${ }^{3}$ Some figures will illustrate this: whereas in 1990 the average additional contribution of Isapre subscribers was $0.7 \%$ of the system's average remuneration, by 1996 it had increased to $1.3 \%$. Between the two years the cost of private medical consultations rose by 55\% in real terms (Baeza and others, 1998, pp. 18 and 19).

${ }^{4}$ For details of Chilean management contracts and their context, see Sojo (1996, 1998 and 1999a).

${ }^{5}$ There are management contracts among other agencies in the health-care sector, but contracts with the health services account for the bulk of health spending, so we shall henceforth refer exclusively to these.

${ }^{6}$ Interview with César Oyarzo, former Director of Fonasa, on 22 August 1997.
} 
in a fragmented way to start with, but progress has been made in rectifying this. ${ }^{7}$

The purchasing function, however, is still a "theoretical" one within the health system. With the exception of some special cases that have only a limited impact on the overall budget, such as complex provision or early treatment programmes, prices are essentially for reference purposes (Lenz, 1998, pp. 193 and 194) and are not laid down by the terms of contracts.

Although contract indicators cover the three levels of health care, they emphasize primary and preventive care. Goals are expressed mainly as indices of activity and coverage. Health indicators, which were very weak at first, have been improved, as has linkage with ministerial and government targets. A rapid rise in the number of indicators has led to an increasingly ritualistic approach being taken to their use, making proper assessment more difficult and creating high transaction costs.

Efforts have been made to optimize the provision network, with the aid of management contracts. Fonasa has become an intermediary among services, and has been restructured into five zones covering a number of services, to achieve network continuity in the regions. Regional committees have been set up to monitor compliance with agreements, ${ }^{8}$ and contracts include activities to strengthen the Programa de Oportunidad de la Atención (Early Treatment Programme), in primary care, and to create a more cohesive system of rural primary care.

Paradoxically, however, implementation -which is the heart of management- has been left entirely to the discretion of the health services, and has not been fully integrated into the agreements. ${ }^{9}$ Organizational objectives or details of which intermediate products have to be purchased have been specified only to a marginal extent, and the same is true of the introduction or improvement of information systems, the optimization of poorly functioning processes, or the development of new processes to make service provision more effective and systematic. There has been no major improvement in record-keeping as an instrument for strengthening management capabilities.

\footnotetext{
${ }^{7}$ Interview of 3 September 1997 with Pedro Croco, then Director of the Management Unit in the Ministry of Health.

${ }^{8}$ Interview with Rony Lenz, then Director of Fonasa, on 26 May 1998.

9 This aspect of the agreements was pointed out by Rony Lenz in the same interview. His references to the weakness of management contracts were made in response to our critical approach to the point in the interview, with which he agreed.
}

To increase the productivity of human resources, the recruitment and pay procedures currently followed will need to be modified. A variety of rigidities in the way human resources are handled are making innovative management difficult. The sectors affected have fought hard to block amendment of law no. 15.076, which governs recruitment and remuneration procedures for professionals in the health services. As a result, no action has yet been taken on a 1995 bill seeking to bring significantly more flexibility and decentralization to employment practices, secure recognition for performance, merit and effectiveness as well as length of service, encourage the allocation of individual responsibilities and link recognition of individual performance to that of institutional performance, and make competitive testing a requirement for remaining in the system (Sojo, 1996).

\section{Integrating management into reform}

Management contracts could play a role in dealing with issues that act as fundamental obstacles to reform. Where charging and cost policies are concerned, for example, the basic information of hospitals is inadequate; in the complex pathologies programme, there is no explicit national referral network. If management contracts included process innovation, useful information could be built up on the quality and costs of care, or criteria of efficiency and effectiveness could be introduced into clinical decision-making. Thus, the failure to integrate management issues properly into contracts limits the impact of these, by preventing beneficial and efficient interaction with sectoral reform.

For example, diagnosis-related pay has not replaced historical budgeting, but has been used experimentally in parallel with this in specific programmes, such as the complex provision and early treatment programmes. When it was first introduced at the hospital level, participation was high and it was not perceived as a threat, but it collapsed because information deficiencies and the diversity of initial conditions made mass take-up unviable. ${ }^{10}$ Consolidating management, through contracts with health services or otherwise, would allow progress to be made with diagnosis-related pay, which could be based on agreed use of clinical protocols, for example. Such a shift would require caution and a sense of priorities.

${ }^{10}$ This experience with diagnosis-related pay was described by Rony Lenz in the interview referred to. 
There is also a need to simplify indicators relating to the fulfilment of tasks specified in goals and coverage targets, and to reduce their number greatly. If it were decided to include some intermediate products, processes and information systems, this would have to be done very selectively and for periods of time long enough for implementation to be consolidated. Management contracts must not be confused with planning by objectives.

\section{III \\ Colombia: management reform in a universal cross-subsidized system, with competition}

The redistributive impact of the Colombian reform has been substantial. In 1993, effective health cover was 13.6 times as great in the top quintile of the population as in the poorest quintile, but by 1997 this gap had narrowed to 1.86 times (Colombia, National Council of Social Security in Health, 2000, p. 13). Reform has aimed both at universal coverage in service provision and at competition among insurers and providers ${ }^{11}$ in a decentralized, cross-subsidized system whose benefits and obligations are consolidated into two regimes: the contributory one, which is funded by worker-employer contributions, and the subsidized one, which focuses on the poorest. The first is regulated by the compulsory medical plan (plan obligatorio de salud, or POS) and the second by the subsidized compulsory medical plan (plan obligatorio de salud subsidiado, or POss). The two are supposed to gradually converge.

The Solidarity and Guarantee Fund seeks to ensure equality and a balance of resources in the contributory system by means of a per capita payment that is adjusted to prevent risk selection in service provision. It has four sub-accounts: compensation, solidarity, promotion, and catastrophic events and traffic accidents. It transfers $1 \%$ of this system's subscriptions to the subsidized scheme, thereby topping up the funding this receives out of general taxation. The aim is to move towards a system in which services are financed by demand subsidy -i.e., financing is determined by actual demand from those insured-instead of by supply subsidy, which is

\footnotetext{
${ }^{11}$ Insurance for the two systems is provided, respectively, by health promotion organizations (entidades promotoras de salud, or EPS) and subsidized system insurers (aseguradoras del régimen subsidiado, or ARS), while health-care provision institutions (instituciones prestadoras de salud, or IPS) operate the actual health services. In all cases, they may be either public or private.
}

the term given to the method traditionally used to finance providers that are overwhelmingly in the public sector, based on historical budgets. Distributive disparities and the position of suppliers as single providers in particular geographical areas have made it impossible to replace the one completely with the other, and no conclusion has yet been reached about the proportion that is desirable.

Both in theory and in practice, however, the Colombian reform shows serious deficiencies as regards the integration and complementarity of the service network and the different levels of care. There is an urgent need to take steps to increase microeconomic efficiency. Management has played a secondary role, and its shortcomings should be tackled as they hinder progress overall (for example, by blocking resources that are indispensable if coverage is to be widened). This is happening just as the contents and rising cost of insurance cover in the contributory system are being reviewed for balance and financial sustainability, while efforts to increase coverage in the subsidized system are being compromised by the decline in funding from the national budget, evasion in the contributory system that affects cross-subsidy resources, and the cost of moving from supply subsidies to demand subsidies (Colombia, National Council of Social Security in Health, 2000, pp. 13 and 20).

\section{Complexities and complications of hospital financing: the repercussions for performance}

In 1993, the intricate architecture of the reform included the transformation of public hospitals into State social enterprises (empresas sociales del Estado, or ESES), which are decentralized public-sector bodies with a legal personality, ownership of assets and administrative 
autonomy (table 1). Decentralization linked public hospitals with the departmental and municipal authorities in their area (table 2), as a result of which the influence of the national authority was weakened and unprecedented tensions arose among these three levels. It has been said that territorial autonomy in the sector is subject to frequent incursions in the form of national rules that detail how territorial health resources can be used (Vargas and Sarmiento, 1998).

Pressure from hospitals for the retention of historical financing, combined with the serious deficits run by some of them, resulted in the plan to replace supply subsidies with demand subsidies being frozen for three years. In the absence of a solid basis of information, the transition regime tolerates double payments to hospitals in the form of supply and demand subsidies, duplications in the insurance for the two systems and the frequent invoicing of policyholders for treatment in order to generate resources from provision (Londoño, Jaramillo and Uribe, 1999). Duplication of payments also takes place at other levels of care, and no adequate records are kept of the insurance and services supplied using specific funds for people displaced by violence. ${ }^{12}$ There is an urgent need to identify, record, cross-reference and unify data on the beneficiaries of the two regimes or of ad hoc funds, on a national basis. This registration process is crucial to avoid leaks and duplication and to administer the insurance and provision systems, but progress has been fitful (Colombia, National Council of Social Security in Health, 2000, pp. 34 and 35).

The budgets for the three levels of public hospitals have risen greatly: between 1993 and 1997, the level I budget increased by a factor of 2.6, that of level II by a factor of 1.9 and that of level III by a factor of 1.5 . Their medical staffs have doubled in the last 10 years, and the wage scales of civil servants in the sector have tripled, yielding a real increase that is higher than the average for public-sector employees. Hospital financing is highly complex, as its different sources each have their own access mechanism, logic, allocation criteria, budgeting systems and resource flows. To compound the complexity, transfers also vary. For example, general public funds earmarked for a hospital or health centre may initially be transferred directly to the municipality, the sectional health fund or the local health fund (Jaramillo, 2000, pp. 45-46 and 108).

\footnotetext{
${ }^{12}$ This subject was raised by Juan Fernando Alviar in a conversation of 22 May 2001.
}

TABLE 1

Colombia: Hospitals operating as State social enterprises (ESEs) as of June 1998

\begin{tabular}{lcrc}
\hline Hospitals & Total & ESES & Percentage \\
\hline Level III & 28 & 23 & 82 \\
Level II & 125 & 120 & 96 \\
Level I & 354 & 194 & 55 \\
Total & 507 & 337 & 66 \\
\hline
\end{tabular}

Source: Colombian Ministry of Health, Programa de Mejoramiento de los Servicios de Salud, included in Londoño, Jaramillo and Uribe (1999).

Resources allocated in accordance with historical budgets come from the national and territorial levels, with funding from the general public budget still the main source of hospital financing. Hospitals and the public social security network are supposed to use these resources to treat people who have no insurance and are unable to pay. So-called "auxilios", contracts with the State to treat poor people, which concealed unconditional transfers, have been abolished.

Large amounts of funding are transferred automatically, or at least are not linked to productivity. Both the complexity and the diversity of public hospital financing make it difficult for the expansion of funding to be linked to the attainment of specified efficiency and performance levels, which weakens these incentives enormously. When the excessive complexity of financing is considered, it needs to be remembered that hospital provision is largely indivisible in respect of the different sources of financing and the incentives underlying them, which makes institutional and organizational change difficult.

Nonetheless, some financing mechanisms do provide for performance incentives. These include the contracts to treat the uninsured population entered into between territorial health funds and public and private hospitals, which make financing conditional on real increases in productivity and efficiency, and which have mainly been applied in Antioquia and Bogotá, with a wide variety of financial and managerial outcomes. ${ }^{13}$

Hospitals need to sell their services to insurance policyholders, so their ability to generate resources of

\footnotetext{
13 These range from successes at the El Tunal Hospital in Bogotá and the San Vicente de Paul Hospital in Medellín to the bankruptcy of institutions such as the Lorencita Villegas Hospital and profound restructuring of the type seen in the San Juan de Dios Hospital in Bogotá (Londoño, Jaramillo and Uribe, 1999, pp. 19 and 62).
} 
TABLE 2

Colombia, official health sector: Distribution of powers and responsibilities after decentralization ${ }^{a}$

\begin{tabular}{|c|c|c|c|c|}
\hline Function & Central or national level & Departmental level & Municipal level & Hospital \\
\hline Financing & ++ & ++ & ++ & + \\
\hline Direction, oversight and control & +++ & + & + & --- \\
\hline Appointment of directors & --- & $\begin{array}{c}++ \\
\text { (Levels II and III) }\end{array}$ & $\begin{array}{c}++ \\
(\text { Level I) }\end{array}$ & --- \\
\hline Planning and investment & --- & ++ & ++ & ++ \\
\hline Setting of pay rates & +++ & --- & --- & --- \\
\hline Recruitment and dismissal & --- & $\begin{array}{c}++(*) \\
\text { (Sectional services) }\end{array}$ & $+(*)$ & $+(*)$ \\
\hline Procurement & + & ++ & ++ & +++ \\
\hline
\end{tabular}

Source: Produced by Londoño, Jaramillo and Uribe (1999).

a The symbols mean the following:

(*) Subject to labour laws and governed by collective agreements. +++ Full powers and responsibility.

$+\quad$ Shared powers and responsibility.

$+\quad$ Minimal powers and responsibility.

--- Absence of powers and responsibility.

their own and achieve real financial autonomy is partly dependent on a crucial variable that is beyond their control: the spread of insurance in the population. Thus, in 1996, services sold accounted for a fifth of hospital revenue, and of this fifth almost half went to the subsidized system. Estimates of the extent to which the coverage of the two systems has increased are controversial. ${ }^{14}$

Meanwhile, territorial organizations and insurers have run up payment arrears with providers, thus causing deficits and cash-flow problems among a large number of level II and III organizations. The rising debt owed by subsidized system insurers to hospitals is unaccountable, as these insurers' subsidized system operations have been in surplus: in 1996, 60\% of their funds were not spent (Jaramillo, 2000, p. 104).

The transition towards municipal decentralization is also making it harder for hospitals to obtain resources, and thus to develop as ESEs; the organizational failings of municipalities militate against hospital decentralization, since in uncertified municipalities ${ }^{15}$

14 Eliminating duplications of data that exaggerate coverage can lead to erroneous estimates of falling or static coverage (Colombia, National Council of Social Security in Health, 2000, pp. 13-17 and 37, and Economic Research Centre, 2000, p. 7). Those who believe coverage has remained static since 1998 attribute this to the implementation of macroeconomic adjustments that had become overdue, higher unemployment, doubts about the subsidized system and vacillation at the national and departmental levels (Jaramillo, 2000, pp. 101 and 88).

${ }^{15} \mathrm{~A}$ form of transition has been established for the decentralization of resources to the municipalities. Although the distinction has been largely discretionary, municipalities that do not meet the technical, the financing chain through which funds from the general public budget pass is a tortuous one. ${ }^{16}$ There is also a fear that the obstacles to resource allocation may "reward local fiscal slackness", if national fiscal resources transferred through the municipality do not ultimately reach the health-care sector (Jaramillo, 2000) or, conversely, if there are delays in the flow of resources that force the territorial level into debt. Huge pension liabilities, ${ }^{17}$ which have not yet been properly dealt with, are also swelling local authority debt (Londoño, Jaramillo and Uribe, 1999, pp. 23, 38 and 59).

With all these variables at work, the financial statements of public hospitals in 1998 and 1999 showed the whole array of situations from deficit to balance or surplus. Deficits have even been covered using resources from the Solidarity and Guarantee Fund that are meant for other purposes. ${ }^{18}$

financial and institutional development prerequisites for receiving automatic transfers receive them with conditions attached through their respective departments.

${ }^{16}$ In this case, a public hospital cannot pay a provider for services or a supplier for inputs without the prior involvement of the Ministry of Finance and Public Credit, the Ministry of Health, the department and its departmental assembly, the municipality and its municipal council, and the relevant subsidized system insurer (Londoño, Jaramillo and Uribe, 1999, pp. 11 and 50).

17 The pension liabilities that local authorities have built up with their employees.

${ }^{18}$ Such as the catastrophic disease and traffic accident sub-accounts, and the solidarity sub-account. 


\section{The regulatory deficit as an obstacle to performance and general effectiveness}

The idea of regulation should be to lay the basis for and oversee the efficient, competitive operation of the market, in accordance with the principles of the healthcare model: universality, integrality, decentralization, coordination, compulsory enrolment, solidarity, freedom of choice, gradualism, efficiency and quality. But there are serious regulatory shortcomings.

For one thing, the absence of clear rules has resulted in a proliferation of insurance organizations whose characteristics and diseconomies of scale mean that they do not necessarily meet the conditions for efficiency. The existence of 200 subsidized system insurers is evidence enough in itself of high transaction costs. Of these, just $4 \%$ have more than 25,000 subscribers, $84 \%$ have between 5,000 and 25,000, and $8 \%$ have less than 5,000 (Londoño, Jaramillo and Uribe, 1999, p. 48). This is reminiscent of the hypertrophy, inefficiency and rising costs of health intermediaries in Argentina, associated among other things with high administrative costs and restrictions on the actual health services guaranteed by the insurers known as "administradoras de cápitas" (Sojo, 1997, p. 47).

Clear evidence of insurers abusing their dominant position makes it urgent for rules and sanctions to be established. Thus, there are the "abuses of certain insurers, particularly subsidized system insurers, that really act as expensive intermediaries rather than carrying out a useful insurance role". For example, there are subsidized system insurers that simply absorb a large percentage of the per capita payment and transfer the balance to a second intermediary, which subcontracts providers. Again, when there is no competition among insurers, payment arrears are compounded by abusive practices whereby tariffs are imposed on hospitals whose negotiating capacities are weak, sometimes in partnership with municipal authorities (Londoño, Jaramillo and Uribe, 1999, pp. 23, 49 and 50). This is quite apart from the fact that this per capita payment, being a non-risk-adjusted general average, is an incentive to adverse selection (Mora and Malabet, 1998).

Again, the way insurers in both the contributory system and the subsidized system delay paying hospitals highlights a serious lack of regulation from which the public hospital system suffers, regardless of performance.

The Ministry of Health is criticized for its weak regulatory capabilities when it comes to laying down general rules to unify the decentralization dynamic. The complaint is that there are no solid minimum guidelines to back up national criteria for employment terms, information quality standards or financial management. Of the fragmented standards of the territorial organizations, it has been said that "rather than a national reform, there may be said to have been numerous local reforms, with varying degrees of progress and little horizontal communication" (Mora and Malabet, 1998, p. 59).

Regulation has also failed to achieve territorial equity in health-care access and a sufficient degree of vertical and horizontal integration among the different levels of care, aspects that are interrelated. Regional or territorial coordination of the service supply network is the responsibility of regional and municipal health directorates, which are supposed to ensure that problems between public- and private-sector providers can be smoothly resolved and that the relations between the two are complementary. The responsiveness of private-sector providers and insurers in smaller and less developed territorial entities was overestimated, however; in economies with large distributional disparities, the market naturally draws private-sector suppliers, particularly high-quality ones, to the highincome sectors (Ocampo, 1996). Combined with the problems of public institutions, this has resulted in serious and costly imbalances in territorial supply (Londoño, Jaramillo and Uribe, 1999, p. 63).

Immediately, then, we have the paradoxes that arise when self-financing hospitals are left to themselves and are not tied in to any system of referral and counterreferral. To deal with these paradoxes there need to be regulations, which could well be incorporated into management instruments such as contracts. For example, the experience of Catalonia and, more recently, that of Costa Rica show that it is possible to create the conditions for integration of the different levels of care and for referral and counter-referral networks by using performance-linked financing contracts, with public-sector organizations and with private-sector ones (Gallego, 1999, pp. 55-57, 76-77 and 265; Franch, n.d., and Sojo, 1998, pp. 94 and 95).

With a few exceptions, ${ }^{1}$ however, the reforms inexplicably neglect epidemiological factors and

\footnotetext{
${ }^{19}$ One exception is the Department of Huila, where steps have been taken to redistribute treatment services among the three hospital levels, strengthening level I and concentrating more specialist care in the other two (Londoño, Jaramillo and Uribe, 1999, p. 54).
} 
necessary measures such as the promotion of preventive care programmes, integration of the different levels of treatment and the creation of referral and counterreferral networks. Since public hospitals were not restructured with reference to territorial supply, but in isolation, the range of services to be supplied by them was left to their own discretion. Most of these hospitals have still not determined fully and explicitly what it is they are supplying. Responsibility for referring patients has presumably been left in the hands of the two systems' insurers, and responsibility for epidemiological follow-up in the hands of the departments, but a systemic vision and the necessary instruments are lacking.

In the same way as in the private sector, public hospitals' need to provide for their own financing tends to restrict the services available to vulnerable sections of society that are unprofitable for them. At the same time as public hospitals, including level I hospitals, have tried to adapt to the new circumstances by creating management instruments such as invoicing and by considering profitability variables, they have allowed the range of services they supply to become unbalanced and have neglected the epidemiological profile as one of the determining factors in their activities, and this has led to an appreciable deterioration in preventive programmes such as vaccination, the early detection of diseases and integral treatment of particular illnesses.

Combined with the segmentation of epidemiological monitoring and the fragmentation of programmes, these factors have resulted in the coverage of vaccinations against tuberculosis, against diphtheria, tetanus and pertussis (DTP) and against poliomyelitis declining during the reform years, in some cases to levels regarded as too low to be effective (Londoño, Jaramillo and Uribe, 1999, pp. 66, 70 and 71, and Economic Research Centre, 2000). ${ }^{20}$ Fundamental issues are also at stake, such as the need to redefine the traditional role of hospitals in vaccination programmes, the costs of which fall appreciably if they are carried out in less sophisticated parts of the health system. Furthermore, hospitals do not have the financing they need to do this work, and since full responsibility for it has not been taken by the municipalities or other bodies, coverage has fallen. ${ }^{21}$

\footnotetext{
${ }^{20}$ This tendency is also manifested in the way human resources in the health sector have grown. Dentists have increased most in number $(52 \%)$, followed by doctors $(47 \%)$, promoters $(19 \%)$ and sanitation technicians (18\%) (Londoño, Jaramillo and Uribe, 1999).

21 Concerns expressed by Juan Fernando Alviar, head of the Rivaralda Public Health Operations Department, in a conversation
}

Decentralization is still a work in progress. The much-criticized sectoral incursions into local autonomy represented by national standards setting out in detail how resources should be used (Vargas and Sarmiento, 1998) have not ensured the comprehensiveness of prevention programmes or the national and local consistency of epidemiological surveillance. Rules are being drawn up to unify promotion, early detection and prevention criteria, content and activities on the basis of "induced demand and the obligation to meet it" over and above passive user demand (Colombia, National Council of Social Security in Health, 2000, p. 27), whose institutional basis has yet to be determined.

\section{From defensive strategies to management reform}

The status of ESEs is ambiguous, and is complicated by the operation of two logics: they can be governed by private law, and they can invoke civil service employment clauses. While employment terms governed by private law allow for collective labour agreements and the creation of unions, civil servants cannot enter into collective agreements.

The manager and board of an ESE can hire nonpermanent staff, buy inputs and invest in equipment, and decide how operating surpluses should be used. Surpluses may be used for employee bonuses, investments or cross-subsidies among services. Inputs, medicines or the services of specialists can be purchased on private system terms. Public-sector bodies are legally entitled, however, to use what are known as "exorbitant" public-sector employment clauses which allow them, for example, to terminate contracts unilaterally. ${ }^{22}$

Discretion in recruitment within a framework of rigidities has meant that most new jobs in hospitals are not permanent, but are generally subject to temporary contracts. Only $18 \%$ of new jobs are staff ones, and this has given rise to a "parallel staff" that has increased from 3,000 to 10,000 people and that can be managed very flexibly (Londoño, Jaramillo and Uribe, 1999, pp. 23 and 43).

The flexibility with which permanent staff members can be managed, meanwhile, is limited by the fact that they still have the status of civil servants

\footnotetext{
held in Santiago on 22 May 2001. In 1999, immunization coverage was extended by an ad hoc programme to purchase vaccines using Solidarity and Guarantee Fund resources (Colombia, National Council of Social Security in Health, 2000, pp. $31 \mathrm{ff}$.$) .$

22 This information was provided by Iván Jaramillo.
} 
and official workers, in accordance with the publicsector selection, appointment and employment system as defined by current labour laws and collective agreements, and enjoy large extralegal benefits. The employment legislation is quite rigid and wage increases are agreed nationally by central government for all staff members in hospitals and welfare centres (Londoño, Jaramillo and Uribe, 1999, pp. 17-19, 6066 and 88-90).

In cases where hospital reorganization has been a success, as in Antioquia, three crucial factors emerge: early measures to increase staff flexibility so that spending in this area can be rationalized, better leadership and management capabilities at the top, and a context in which insurance plays a stronger role (Londoño, Jaramillo and Uribe, 1999, p. 65).

Experiments with changes to public hospital incentives have involved instruments such as contracts, accountability mechanisms, greater autonomy in financial and administrative areas such as procurement and recruitment, the retention of efficiency savings to be used for productivity bonuses, information systems to follow up performance and productivity, surveys to measure user satisfaction, changes to staff composition and working hours in hospitals, and invoicing systems. ${ }^{23}$ These experiments aside, there has been little innovation in employment practices. There are no general performance indicators to measure improvements in efficiency and equity in autonomous hospitals, and there have been no agreements relating to the use of forward payments and historical budgets; more than $60 \%$ of municipalities are under investigation for diversion and misuse of health-care resources (Londoño, Jaramillo and Uribe, 1999, pp. 50 and 59).

When solidarity and universality are being pursued within a competitive framework, public-sector management reform needs to foster genuinely competitive and complementary relationships between the public and private sectors, make it possible for the public sector to compete on cost and quality, and contribute to better design of the public-private mix. It is thus essential to systematize the positive and negative aspects of the experiments carried out so that reform can be undertaken, at least gradually, in the management of the hospital network as a whole.

Conversely, it does not seem advisable to apply strategies to defend and protect the public sector from competition, if this means delaying or avoiding urgent

${ }^{23}$ Examples include the Garcés Navas Hospital, the El Tunal Hospital and the Jorge Bejarano Children's Clinic. management reform. This is what the Social Security Institute (ISS) did, choosing to cope with competition within the contributory system by adopting an eminently defensive strategy, rather than increasing its efficiency and effectiveness by undertaking far-reaching management reforms at the time competition was introduced. It was then granted certain protective advantages or privileges: it could combine insurance and provision functions, it was not required to collect co-payments, and it was authorized to offer an extended benefits plan that was not subject to the waiting periods ${ }^{24}$ prescribed by law (Londoño, Jaramillo and Uribe, 1999, p. 47). Despite all this, Iss ran up deficits and saw its asset position deteriorate, the result being a crisis of such proportions that it has been debarred from taking on new subscribers since mid-1998.

Again, to give greater security and protection to the public network and make the provision of health services to the poorest more attractive, Law 344 of 1996 required subsidized system insurers to contract for a compulsory minimum of services with public hospitals, equivalent to $40 \%$ of the resources of the subsidized system. In some regions of the country, hospitals or their unions have refused to turn themselves into ESES and forfeit historical budget financing, and there has been pressure for the subsidized system to be tied to the public hospital network. Level I hospitals have been the most reluctant to turn themselves into ESES. The transformation of supply subsidies into demand subsidies was frozen because of the illiquidity of some public hospitals (Jaramillo, 2000, pp. 37, 38 and 58).

As of late 1998, about a third of all high- and medium-complexity hospitals were resisting modernization. They had not adapted their organizational structure to the new legal framework, and in many cases they were being run by interim managements that were too unstable to bring about transformation and improvement. Some hospitals were prevented from adapting to the new model by the overwhelming inflexibility and inefficiency of their old structures, and had to close. Others, faced with the possibility of liquidation, pressed for greater resources that were not tied to productivity (Londoño, Jaramillo and Uribe, 1999, pp. 49 and 64).

Certain management changes are important because of their role in supporting other aspects of

\footnotetext{
${ }^{24}$ When an insurance policy is initially taken out, waiting periods apply. These require a set amount of contributions to have been paid before certain services and benefits can be taken up, the purpose being to ensure the stability of contributions.
} 
reform. For example, to determine the cost of capitation units accurately and progress with price negotiation, it is essential to have reliable records on activity, costs and quality, and invoicing systems that enhance management capabilities.

Many of these challenges can be dealt with if consensus is achieved. As in the case of decentralization, the political realities of the process need to be recognized if general agreement is to be reached on the best way of dealing with new challenges and problems. Similarly, the fragmentation of responsibilities among the different levels of government and the complexity or lack of clarity characterizing regulations are often the result of unsatisfactory negotiations among the opposing interests affected (Chiappe, 1999, p. 3).

\section{IV}

\section{Argentina: the diversity of hospital decentralization}

In Argentina, reform has had two pillars. One has been the promotion of free choice and of efficiency and equity among health insurers, which are known as "obras sociales" (social organizations); there has recently been legislation to address the excessive proliferation of the financial intermediaries known as "administradoras de cápitas". The other pillar has been hospital self-management, which is supposed to raise efficiency and thus address the major challenges posed by the excessive size of hospitals, cross-subsidies to health insurers, inadequate referral and counter-referral systems, deep-rooted conservatism in management practices and vagueness about the way some functions are to be financed -teaching being an example- under the self-management system (Sojo, 1997 and Tafani, 1997).

\section{The spirit and instruments of hospital reform}

In 1993, the general legal framework for hospital autonomy was created by decree. This envisages selfmanaged public hospitals being grouped into a system of hospital-centred health service networks which are supposed to link up and coordinate the health services supplied by public- and private-sector providers in a system of universal, compulsory coverage, with a pluralistic, ${ }^{25}$ participatory and administratively

\footnotetext{
${ }^{25}$ The idea of pluralistic participation is reflected in the make-up of boards. In the case of a public-sector insurer such as the Salta Provincial Health Insurance Institute, for example, the board consists of a chairman and five directors. The chairman is appointed by the government on the recommendation of the Ministry of Public
}

decentralized structure. It also stipulates that the health insurers should pay hospitals for the services received by their policyholders, and establishes a mechanism whereby the debts that the insurers accrue with hospitals are automatically deducted from the subscription transfers made to them.

The separation of functions has been carried out in accordance with the situation in the provinces, and regulation is envisaged, in certain areas, as being decentralized. This creates the risk that regulation may be fragmentary and atomized, lacking a national framework of rules to back up the minimum criteria, guidelines and standards applicable to the contractual relationships between insurers and providers, and to the quality of provision or management.

In the case of Salta, ${ }^{26}$ for example, the board of the insurer lays down the provisions governing the different forms of contractual relationship between it and providers and participates in drawing up and

\footnotetext{
Health. The directors represent public-sector providers, privatesector providers, the health insurers with the most policyholders in the province, municipalities with institutional autonomy and policyholders themselves. The Ministry notifies the government executive of the candidates it has chosen from the shortlists of three submitted by the relevant organizations and is represented at the creation of the Standing Coordination Commission (Comisión Permanente de Concertación), which is chaired by the secretary of health services or his deputy and composed of representatives of the board of the Provincial Health Insurance Institute and the majority representatives of providers at the provincial level (Argentina, Government of, 1998b).

${ }^{26}$ By virtue of the bill to enact the Salta Provincial Health Insurance Institute constitutional law (Argentina, Government of, 1998b).
} 
updating the regulatory instruments used. The Standing Coordination Commission is responsible for drawing up the rules, procedures and standards of usage that service provision must comply with, and for setting payment procedures and amounts. This last could blur the dividing line between the financing function and the provision function, and could lead to coordination in these areas becoming confused with regulation, a power that should remain in the hands of the purchasing body.

The management reform provides for improvements in processes, such as the creation of a unified medical register in the case of Mendoza, databases for identifying the patient population, the provision to all users of confirmation documents linking them to the relevant medical centres, and the maintenance of up-to-date medical records. An effort is also being made to raise quality standards by means of Citizen Charters (Cartas de Compromiso con el Ciudadano), which explain the services available and the quality standards that are to be met (Neirotti, 1999).

Factors that are believed to have helped create consensus among influential actors in relation to hospital reform include training for the professionals involved, early measures to increase understanding of the reforms applied to hospitals and health insurers, ${ }^{27}$ and pilot projects that have placed a strong emphasis on organizational development in the city of Buenos Aires, in the provinces of Buenos Aires and Mendoza, and to a lesser degree in other places (Abrantes, 2000). ${ }^{28}$

Hospitals that operate under the self-management system can enter into contracts with insurers and with suppliers of services that the hospital itself does not provide. They can assign, promote and transfer employees within their staff. They can exercise a degree of control over their operating plan and annual budget. They can sell services, collect co-payments that vary by income group and use this income, along with the revenue from health insurers, for staff productivity incentives, investments or maintenance. Experiments are being carried out with independent financing of the training and education functions carried out by hospitals.

\footnotetext{
27 The relevant documentation can be consulted at http:// www.msal.gov.ar/pressal.

${ }^{28}$ Hospitals participating in these pilot projects hosted a resident team of hospital management consultants who worked with the hospital management to define their mission and objectives, develop a medium-term plan and coordinate short consultancy projects dealing with specific issues (Pressal, 1998).
}

\section{Hospital management contracts}

Management contracts for hospital financing, which are supposed to replace historical budget financing, have gradually been coming into use since 1998 as a "legal fiction" for familiarization purposes. Because of decentralization, hospitals were already attached to provinces, and in some cases to municipalities, when the process began. Consequently, hospital selfmanagement has developed slightly differently from place to place, and no single management contract model has been applied, the idea being that contracts in each province should reflect the way the separation of functions has been organized there (Sánchez de León, 1998, p. 50). ${ }^{29}$

For example, the change in prospect is most radical in Salta, where the management contract should be instrumental in introducing what in Chile and Colombia has been called the "demand subsidy" resource allocation method. In La Pampa, on the other hand, the emphasis has been put on the economic incentives that can be redistributed in self-managing hospitals from the funds generated by invoicing health insurers. In Santa Fe, again, efforts are being made to consolidate a decentralization model that has been operating for several decades, by applying a management contract (Pressal, 1998, p. 11). A few hospitals in each province have been chosen to work with management contracts (ibid., p. 32).

Management contracts sometimes include quite detailed targets, with activity and efficiency indices (average days of hospitalization, number of discharges, number of operations) and quality indices (days of hospitalization before surgery, waiting time at the prediagnostic and laboratory stages, formation of hospital infection committees). As regards staff, the aim is generally to reduce absenteeism and encourage training (Argentina, Government of, 1998a; Neirotti, 1999; Abrantes and Días Legaspe, 1999 and Abrantes, 2000).

Other contracts include a wider range of aspects connected with process improvements and participation in the provider network, resembling the complex management contracts of Costa Rica. Thus, in the case of La Pampa contracts include (with differences of emphasis in each hospital): compliance with diagnostic and therapeutic protocols, referral and counter-referral procedures, resolution capabilities corresponding to the

${ }^{29}$ For examples of theoretical proposals and provincial experiences, see Pressal (1998). 
level of complexity, updating of medical records and the registry system, consolidation of the gatekeeper system, measurements of user satisfaction, community education programmes, and implementation of prevention programmes (Pressal, 1998, p. 40).

Substandard invoicing systems are being upgraded. Recovery of costs from insurers has been improved, making it possible to offer individual performance bonuses that in some cases can double doctors' incomes. Because hospital reform is taking place within a framework of fiscal discipline linked to provincial reform projects, the provinces have restricted hospitals' financial independence and freedom to recruit staff. The financial slack from which incentives are paid has had to come essentially from efficiency gains, revenue from services provided to insurers, co-payments and reductions in the proportion of spending that goes on staff, where there is scope for this (Abrantes, 2000).

As was pointed out earlier, financing the incentive system from social security charges and invoicing, while it may initially boost production, carries with it an incentive to practise selection to the detriment of the uninsured population. In the interests of equity, therefore, it is important to design budgets with flexible components that can be used for incentives (Pressal, 1998 , p. 51). It has also been noted that pay supplements financed out of charges to the different insurers have not always been linked to performance incentives. In Mendoza, for example, these incentives were granted in 1998 to professionals and non-professionals, while managers were excluded, but as part of a "more for the same" distribution scheme (ibid., p. 38).

\section{The degrees of hospital autonomy}

Where degrees of hospital autonomy are concerned, three basic situations can be broadly distinguished at the territorial level. ${ }^{30}$ In the provinces of Entre Ríos, Formosa, La Rioja, San Luis, Santiago del Estero and Tucumán, most hospitals are still financed on a historical budget basis, and their autonomy is very restricted. In Salta and San Juan, on the other hand, hospitals operate as trusts, are governed by public and

\footnotetext{
${ }^{30}$ Distinction drawn by Abrantes (2000).
}

private law, have freedom to manage their staff and assets and can use the resources they generate as they see fit.

Management contracts have been concluded between hospitals and provinces and among hospitals; these contracts include some performance indicators relating to efficiency and service quality. Hospitals have to compete with other public- and private-sector providers, and the customer base is segmented between those who have insurance or pay for services on the one hand, and the uninsured poor who are treated for free on the other. Managers have fixed-term contracts that are not aligned to the political cycle. Internally generated revenue can be used for investments, maintenance and staff performance incentives. In Salta, Tucumán and San Juan, poor and uninsured users should be able to choose between public- and privatesector providers from 2003 onward.

The largest hospitals in Corrientes, Catamarca, La Pampa, Mendoza and Río Negro are in an intermediate situation. These are financed on a historical budget basis, have administrative and technical councils that appoint managers, and have acquired a degree of autonomy over inputs other than human resources. They can retain up to $80 \%$ of revenue from services to insured users and use this for performance incentives, investments and maintenance. Where staff are concerned, although the hospitals can promote employees and encourage them to take early retirement, they cannot recruit or dismiss them. While contracts contain performance indicators, only in Río Negro are individual performance bonuses linked to success in meeting targets. The provinces of Buenos Aires, Entre Ríos and Santa Fe have similar legislation, but change has been relatively slow or inconsistent.

The Dr. Juan Garraham National Paediatric Hospital in Buenos Aires, which is a level III (referral) one, and the José de San Martín Teaching Hospital, which is the University of Buenos Aires teaching hospital, are public-sector enterprises that have full control of their budgets and their own revenue, and full responsibility for the debts they incur, although the San Martín Hospital recently succeeded in obtaining a bailout for a significant debt that it had accumulated. Both are remarkable for the amount of investment and maintenance revenue they are generating on their own, amounting to almost a third of their budgets. 
V

\section{Management contracts in a predominantly public system: Costa Rica ${ }^{31}$}

In the midst of an advanced epidemiological and demographic transition, Costa Rica, which has achieved effectively universal health cover with its public health system, is seeking to improve the efficiency and effectiveness of the public-sector institutions providing health services. The crux of the reform, which has been implemented gradually since 1996, is the introduction of management contracts.

The aim is to move beyond the implicit and explicit pattern of traditional management at the Costa Rican Social Security Fund (CCSS), a body which acts as both insurer and provider, and its underlying system of negative incentives, which is characteristic of traditional, non-performance-related financing: inequality in the supply of services, which is influenced by the leverage of each centre; indifference to user dissatisfaction; medical agendas that give rise to a kind of captive market controlled by specialists; administrative control of the budget and ignorance of the cost of services; pay determined by length of service and not by assessment of staff performance; a high level of absenteeism, replacements and incapacities; and selfregulation by professionals in the sphere of clinical management.

\section{Reform instruments}

In 1997, CCSS separated its internal financial and service provision functions, and it has since created a procurement function, although this is still at the gestation stage and has not yet been fully separated from the financial function. Management contracts with hospitals and health areas were introduced gradually and selectively until by 2000 coverage was complete, but the resources earmarked for the procurement function did not increase proportionately.

This quasi-market is subject to a great deal of internal regulation, as it is the central level of CCSS that has the power to collect funds directly, set rules, carry out regulation and make appointments to key posts. This entails intense internal negotiations, however, since the

${ }^{31}$ For a detailed study, see Sojo (1998 and 1999b). basic decisions are taken by the cCss board. The procurement function is monopsonic, as there is no provision for micropurchasers or mesopurchasers, while the provision function is deconcentrated, being spread around numerous CCSS and cooperative bodies.

A new financing model is being promoted, the guiding principles being solidarity, universality and equity. The theoretical financing model includes a variable budgetary component that is tied to the achievement of goals and objectives. This amounts to $10 \%$ of the total budget and is divided equally between an incentive fund and a solidarity fund to cope with unforeseen expenses during budget implementation. At the first level of care, there is to be a shift from historical financing towards per capita payments adjusted for the pattern of service use as determined by the infant mortality rates and sex and age structures of the populations served, the aim being to reverse the current inequalities in local resource allocation. At the second and third levels of care, the overall activity of each hospital is broken down initially into four areas: hospitalization, out-patient care in specialist and nonspecialist surgeries, emergency, and teaching, research and special welfare programmes. For these, a homogeneous unit of production is established, consisting of a standard equivalence coefficient known as the hospital output unit (unidad de producción hospitalaria, or UPH). The target values for the hospital output unit, the main factor in which is the length of hospital stays, are laid down in a schedule that is invariable for the life of the agreement. The objective at these levels is to move eventually towards a system of payment by case mix or related diagnostic groups.

Historical budgets were taken as the baseline for the change, and 1994 data were used to construct an output function. A dry run has been in operation since then, so that the resources provided are still not tied to compliance with agreements or to the new financing model.

\section{Paradoxes of contractual complexity}

Measuring performance, which is what these agreements are essentially designed to do, generates 
process innovations that can help to systematize service provision, illuminate specific aspects of its effectiveness, restructure provider organizations and modify their management culture. To be effective, it requires the creation and maintenance of reliable records on activities, costs and quality, and information systems that can strengthen management capabilities. It also encourages the use of interesting and potentially very important instruments, such as clinical protocols. Contracts are specific to health areas, and to the second and third levels of care, although convergence is taking place where the aspects under consideration are concerned. ${ }^{32}$

By contrast with Colombia, where, as we have seen, preventive health care and referral systems have been neglected, these contracts promote improvements in the organization of the health system and service provision; in particular, they encourage interaction among the three levels of care. Where the health areas are concerned, they reward the ability to resolve cases and reduce referrals, and encourage prevention and promotion activities to reduce sickness and death rates and consolidate desirable health conditions over the medium and long term. Where hospitals are concerned, they lay down referral system rules and in some cases specify a hospital network that is to be consolidated. They encourage second-level institutions to carry out consultation and training activities for the first level, and promote measures to check the actual coverage of the enrolled population.

Importance is also given to the quality of care, which is envisaged as a continuous process of improvement. Quality measurement is provided for in the form of indicators relating to the effectiveness of medical services (patient health complications, trend of the death rate and causes of death, etc.), or in the form of procedures to ensure that medicines are properly used, improve individual health records or control hospital infections. There is concern to improve aspects relating to the promptness and accessibility of treatment so that resource use can be optimized. For this purpose, some efficiency indices have been established (reduction of waiting lists, handling of emergencies, better use of installed capacity such as operating theatres, reduction of medical absenteeism, improvements to support services such as pharmacy services). Measures to identify staff responsibilities and

\footnotetext{
${ }^{32}$ For a detailed discussion of the characteristics of these agreements and of the financing model, see Sojo (1998).
}

processes have been adopted, as have mechanisms to ascertain user satisfaction and deal with complaints.

Although progress has been made in creating the conditions needed for invoicing to be viable (something that is essential for the new financing model), these conditions have not yet been applied. Evaluation criteria have gradually been standardized and progress has been made in refining the criteria for classifying output and verifying production budgets in accordance with the activities of providers. ${ }^{33}$

The ever-increasing variety of indicators used in contracts, however, and the wide range of objectives, could make them difficult to apply, complicate any evaluation that looks beyond quantitative criteria to seek to identify the conditions that work for and against compliance, and result in excessive transaction costs. This suggests there is a need to rank indicators by importance, limit their number and ensure continuity, if changes in processes and information systems are to be consolidated.

For the same reason, objectives and goals should be scaled down. The format of agreements, the range of aspects and indicators included, and the fact that resource transfers have not yet been made conditional on compliance, mean that contracts resemble a form of planning by objectives, isolating or crystallizing certain priorities and aspects of organization and service provision that providers are asked to comply with. This may have something to do with the decision to make the process a gradual one, as this resulted in a "conservative" specification of the products to be purchased at an initial stage, both in quantitative terms, as historical budgets were used as the baseline, and also in terms of the classification of these products by factors, to determine both the objectives and the indicators to be evaluated (Guzmán, 1999, p. 60).

Although this decision may have helped to prevent turmoil in units by ensuring the coexistence of traditional elements that are tied in to the reform through

\footnotetext{
${ }^{33}$ Where hospitals are concerned, for example, consideration has been given to the degree of comparability among centres, and they have been segregated so that four sets of activities can be assigned to them: a) social security, which is regarded as comparable and measurable in hospital output units; b) key specialisms, such as those of San Juan de Dios (burns), Calderón Guardia (liver transplants) or México (heart transplants); c) extraordinary activities, such as measures to combat dengue or cholera; d) investments, for which there was previously no systematic financing. Interview with René Escalante, manager of the Administrative Division of CCss, 10 December 1998.
} 
contracts, it could also result in agreements having an excessive degree of complexity that proves difficult to manage over time, complicates evaluation and entails high transaction costs -the amount of information that has to be obtained from providers, for example- that may result in the agreements being mired in bureaucracy, or becoming a dead letter.

Introducing financing by capitation, case mix or related diagnostic groups will allow progress to be made towards a set of agreements whose essential aims are the effectiveness and efficiency of provision. Other aspects of management reform, such as support for the use of evidence-based medicine, can be linked to other instruments that are integrated into essential activities, such as epidemiological surveillance. Organizational aspects and intermediate products, while not excluded, will undoubtedly have to be emphasized less in agreements.

\section{The legal basis}

It is essential for contracts to be legally sound, as it is this that determines not only the scope for applying effective sanctions in the event of non-compliance, but also the way conflicts are resolved within the market, the rank of the authorities involved and the mechanisms to be used for dealing with contractual omissions and oversights and resolving disputes, among other aspects (Walsh, 1995).

The management contracts of CCSs first acquired a legal basis when they were approved by the board of that institution. But in legal terms, these were "quasicontracts", since hospitals and clinics had no legal personality of their own. A crucial step towards legal solidity was the act of parliament deconcentrating CCSS hospitals and clinics, which made the management contract the instrument that articulated and delimited this deconcentration by establishing that hospitals and clinics enjoyed an "instrumental legal personality" for the purposes of "budgetary management, administrative recruitment and the management and organization of human resources subject to the legal provisions applicable, the limits set by the Fund and the management contract". According to the person who promoted it, ${ }^{34}$ an instrumental legal personality is stronger than that of a deconcentrated body but weaker than that of a decentralized one, as it is exercised strictly within the spheres determined by law and delimited by the agreement.

\footnotetext{
${ }^{34}$ Interview of 7 December 1998 with Rodolfo Piza Rocafort, executive president of cCss.
}

The deconcentration act also stipulated that the organizations were to be run by the director, who was to act in accordance with the objectives and obligations set forth in the management contracts, with general regulations and with the policy guidelines issued by CCSS.

But reality always makes change awkward, and in this case the provisions of the law reflect resistance to rule changes. The legal changes were sought by the CCSS executive, which has set itself no deadline for completing the process, as it is trying to ensure it is not traumatic. However, expectations and interpretations of the scope of the law are not uniform among different agencies of CCSS, where the prevailing interpretation is that administration will be deconcentrated only to a limited degree, while providers expect to achieve a high degree of autonomy in the very near future. The regulations support the view of limited administrative deconcentration more than that of decentralized powers and managerial independence (Guzmán, 1999, p. 82).

In addition, fundamental issues have yet to be resolved if the legal framework is to be consistent with new methods of assessing staff performance. There would need to be amendments to the statutes of the medical and nursing services that govern membership of their professional bodies and determine how recruitment and assessment are carried out within the civil service system. ${ }^{35}$ The way professionals are regulated under these statutes is an impediment to managing them within CCSS. Among other problems, it gives rise to conflicts of supervision, hinders the effective performance of duties and encourages a trade unionist attitude among staff (Ortiz and Sequeira, 1998, pp. 99 and 100).

\section{Staff performance}

The preponderance of medical professionals and paramedical staff very largely determines the nature of the services provided, and the new incentive systems are reshaping their power and affecting their room for manoeuvre. To lay the basis for relationships of trust under a new management model, and to ensure that staff performance is adequately monitored, there is an urgent need to change the staff recruitment and selection practices and the retention rules currently followed in CCSS.

\footnotetext{
${ }^{35}$ See University of Costa Rica (1998), cited by Ortiz and Sequeira (1998, pp. 36 and 37).
} 
Security of employment that is detrimental to performance, career progression by length of service rather than merit, the agreement that four to five patients should be seen an hour, the tortuous procedures for dismissing staff ${ }^{36}$ and the inability of patients to choose their doctor are all obstacles to thorough change in the situation and, in general, to modernization of human resource management in CCSS.

Changes need to be made to the criteria that govern public service recruitment and retention, as the inflexibility of employment terms is unquestionably a crucial element that can be an obstacle to innovative management. Staff appointments should be decided by competition, promotion and pay should be based on assessments of career performance, procedures for dismissing staff should be simplified, and terms of employment should be standardized. The efficiency and productivity gains thus achieved could feed through to improvements in pay based on the new criteria. In the interests of equity, steps will have to be taken to ensure that there is a balanced distribution of the necessary human resources in all geographical areas.

\section{VI \\ Conclusion}

By concentrating on insurance and financing, the health reforms carried out in the region have not always paid sufficient attention to the organizational and institutional variables associated with these. Management changes have taken place in systems that differ in terms of solidarity and universality. Chile lags furthest behind when it comes to changes in financing and action to remedy the shortcomings of management contracts. In Colombia, the country that has perhaps made most progress in building up a new financing

\footnotetext{
36 The procedures for dismissing staff need to be simplified nationally. At present, they involve due process applications, appeals, the local commission and the central commission for labour relations. The problem is that a bill is needed to regulate this issue, and the basis of employment needs to be standardized for the different sectors. These are some of the challenges described by Dr. Elías Jiménez, then director general of the National Children's Hospital, in an interview conducted on 5 February 1998.
}

The range of CCSS-financed private-sector provision is currently being extended, to cut waiting lists for specialities. Care should be taken here to ensure that the movement of professionals between the two sectors and the moral hazard this may involve do not lead, for example, to CCSS professionals deliberately reducing their productivity or neglecting tasks such as proper equipment maintenance. It is worrying to reflect that as restrictions are removed, pockets of inefficiency may become entrenched in CCSS provision, when the process should actually be contributing to the reduction of waiting lists. Nor should this process place a constraint on CCSS infrastructure and equipment investment, as this would result in back-door restrictions on public-sector provision and possibly escalating costs, if the prices paid to the private sector were higher than the price levels that CCSS should be able to achieve if it were operating efficiently. Again, co-payments (e.g., to receive faster treatment in the private sector) should not be introduced if they undermine the solidarity of the system. system and the rules to govern it, hospital financing is excessively complex and suffers from the negative effects of financial intermediation. Although the country can show successes with pilot projects, most hospitals are relatively neglectful of management and are only loosely tied in to referral and counter-referral networks. In Argentina, the most striking feature of hospital reform is the variety of forms taken on by hospital selfmanagement, as this was introduced in a decentralized context; there is currently discussion of regulating risk selection, improving performance measurements as a basis for the provision of incentives, moving towards financial autonomy and taking steps to deal with excessive hospital size. In Costa Rica, financing changes are still at the experimental stage; the country's management contracts are interesting because of the changes they imply for processes, decentralization and improvements to the institutional network, although their growing complexity may militate against their objectives. 


\section{Bibliography}

Abrantes, A. (2000): Contracting public health care services in Latin America, in A. Preker and A. Harding, Innovations in Health Care Delivery, Washington, D.C., World Bank.

Abrantes, A. and A. Días Legaspe (1999): Contracting public health care services in Latin America, paper presented at the First Europe and Latin America and the Caribbean Forum on Health Sector Reform, World Bank, Paris, May.

Argentina, Government of (1998a): Anexo. Modelo de contrato de gestión. Estructura base, Buenos Aires, mimeo.

(1998b): Proyecto de ley orgánica del Instituto del Seguro Provincial de Salud de Salta, Buenos Aires, January.

Bach, S. (1999): Trends in European health sector reform: Implications for human resource management, paper presented at the Reunión constitutiva del Observatorio de los recursos humanos en las reformas sectoriales de salud, Santiago, Chile, World Health Organization (who)/Pan American Health Organization (PAHO), June.

Baeza, C. and others (1998): El sector de la salud en Chile: un diagnóstico compartido, Santiago, Chile, December, mimeo.

Chiappe, C. (1999): Elementos de análisis para una estrategia educacional de Colombia, Washington, D.C., Inter-American Development Bank (IDB), Sustainable Development Department, Human Resources and Social Development, Social Programs Division, mimeo.

Chile, Ministry of Health (1998a): Estrategias innovadoras en salud. La reforma programática y financiera chilena, Santiago, Chile, April.

(1998b): Políticas y estrategias innovadoras en salud. Reforma programática 1998, Santiago, Chile, August.

CIE (Economic Research Centre) (2000): Monitoreo del sistema de salud en el Departamento de Antioquia, Medellín, Colombia, University of Antioquia, mimeo.

Colombia, National Council of Social Security in Health (2000): Informe anual del Consejo Nacional de Seguridad Social en Salud a las comisiones séptimas del Senado de la República y Cámara de Representantes, Bogotá, July.

Consultora ASENSA, Asesores en Salud, S.A. (1997): Consultoría para el proyecto de fortalecimiento institucional Hospital Dr. Eduardo Castro Rendón. Provincia de Neuquén (Resumen), Documentos del Pressal, Buenos Aires, Pressal, September, http://www.msal.gov.ar/pressal.

ECLAC (Economic Commission for Latin America and the Caribbean) (2000): Equity, Development and Citizenship, LC/G.2071, Santiago, Chile.

Fasano, V. and M. Álvarez (1997): Sistemas de información en salud. Marco conceptual, Buenos Aires, Ministry of Health and Social Welfare, Secretaría de Acción Social, Documentos del Pressal, http://www.msal.gov.ar/pressal.

Ferlie, E., L. Ashburner and others (1996): The New Public Management in Action, Oxford, U.K., Oxford University Press.

Franch, L. (n.d.): Compromisos entre financiador público y proveedores de servicios, in Apresal (Proyecto de apoyo a la reforma del sector salud), La reforma del sector salud, Guatemala City.

Gallego, R. (1999): New public management. Reforms in the Catalan public health sector, 1985-1995, London, London School of Economics and Political Science, Government Department, Ph.D. thesis.

Guzmán, A. (1999): Los compromisos de gestión en Costa Rica,
1997-2000, Madrid, Universidad Alcalá de Henares, July, Master's thesis.

IPSS-Tucumán (Instituto de Previsión y Seguridad Social de la Provincia de Tucumán) (1997): Estudio diagnóstico del IPSSTucumán, Documentos del Pressal, Buenos Aires, Proyecto de Desarrollo del Sector Salud en las Provincias Argentinas (Pressal), 16 October, http://www.msal.gov.ar/pressal.

Jaramillo, I. (2000): ¿Qué es y qué pasa con el régimen subsidiado de salud? Descripción y diagnóstico preliminar, Bogotá, Ministry of Health, Programa de Apoyo a la Reforma de Salud, January, mimeo.

Jaramillo I., L.H. Sánchez and M. Ramírez (2000): Evaluación de la ley 100 de 1993. Seis años de su puesta en marcha, Bogotá, Asociación Colombiana de la Salud, Grupo de Macropolíticas, April, mimeo.

Le Grand, J. (1999): Los nuevos desafíos de la política social: Estado, mercado y equidad. La experiencia del Reino Unido, in J. Carpio and I. Novacovsky (comps.), De igual a igual: el desafío del Estado ante los nuevos problemas sociales, Buenos Aires, Fondo de Cultura Económica (FCE).

Le Grand, J. and W. Bartlett (eds.) (1993): The theory of quasimarkets, in J. Le Grand and W. Bartlett, Quasi-markets and Social Policy, London, Macmillan Press.

Lenz, R. (1998): Contribution included in: Chile, Ministry of Health, Políticas y estrategias innovadoras en salud. Reforma programática 1998, Santiago, Chile, Ministry of Health.

Londoño, B., I. Jaramillo and J.P. Uribe (1999): Descentralización y reforma en los servicios de salud: el caso colombiano, Bogotá, World Bank, December, mimeo.

Mora, H. and M.P. Malabet (1998): Utilizaciones de servicios del Plan Obligatorio de Salud Subsidiado en una muestra de Administradoras del Régimen Subsidiado en Santafé de Bogotá, Coyuntura Social, No. 19, Bogotá, Foundation for Higher Education and Development (Fedesarrollo), November.

Murray, C. and J. Frenk (2000): A WHO framework for health system performance assessment, Discussion papers, No. 6, Washington, D.C., wHO, wHO Statistical Information System (wHOSIS), http://www-nt.who.int/whosis.

Neirotti, N. (1999): Control de gestión en políticas de salud. El caso de Mendoza, Argentina, mimeo.

Ocampo, J.A. (1996): Participación privada en la provisión de los servicios sociales: el caso colombiano, Coyuntura social, No. 14, Bogotá, Foundation for Higher Education and Development (Fedesarrollo).

Ortiz, K. and S. Sequeira (1998): Análisis de los compromisos de gestión como instrumentos facilitadores del cambio organizacional en la Caja Costarricense del Seguro Social, San José, University of Costa Rica, December, Master's thesis.

Pressal (1998): $1^{o}$ Seminario Regional. Contrato de gestión. Su implementación en las provincias, Cuadernos del Pressal, No. 1, Buenos Aires, Pressal, http://www.msal.gov.ar/pressal.

Porter, D. (1999): Health, Civilisation and the State. A History of Public Health from Ancient to Modern Times, London, Routledge.

Ramírez, G. and others (1998): Evaluación de tecnologías sanitarias y cuidado de salud basado en evidencias: herramientas para la reforma, in Chile, Ministry of Health, Políticas y estrategias innovadoras en salud. Reforma programática 1998, Santiago, Chile, August. 
Rendón, P. and I. Jaramillo (1999): Evaluación del programa de mejoramiento de los servicios de salud en Colombia, Bogotá, Ministry of Health, May, mimeo.

Salinas, H. (1988): Conferencia de clausura, in Chile, Ministry of Health, Políticas y estrategias innovadoras en salud. Reforma programática 1998, Santiago, Chile, August.

Sánchez de León, A. (1998): Implementación de los contratos de gestión, in Pressal, $1^{\circ}$ Seminario Regional. Contrato de gestión. Su implementación en las provincias, Cuadernos del Pressal, No. 1, Buenos Aires, Pressal, http://www.msal.gov.ar/ pressal.

Sanhueza, G. and C. Jarpa (1998): Costo-efectividad en la toma de decisiones en salud, in Chile, Ministry of Health, Políticas y estrategias innovadoras en salud. Reforma programática 1998, Santiago, Chile, August.

Sojo, A. (1996): Potential and limits of health management reform in Chile, CEPAL Review, No. 59, LC/G.1931-P, Santiago, Chile, ECLAC.

(1997): La reforma finisecular del sector salud en América Latina y el Caribe: su derrotero e instrumentos, in Costa Rica, Ministry of Health / UNICEF (United Nations Children's Fund), Costa Rica. Las políticas de salud en el umbral de la reforma, Políticas sociales series, No. 1, San José.

(1998): Health management contracts in Costa Rica from a comparative perspective, CEPAL Review, No. 66, LC/G.2049P, Santiago, Chile, ECLAC.

(1999a): Los compromisos de gestión en salud de Chile: formas de reintegración en el rompecabezas de la reforma, in National Health Fund, FONASA: ¿ una reforma en marcha? Una mirada interna y externa a las políticas y planes del Fondo Nacional de Salud, Santiago, Chile, July.

(1999b): Los compromisos de gestión en salud de Costa Rica: algunas lecciones de un cuasimercado germinal, in
ECLAC, Taller sobre evaluación de la gestión del gasto público en salud. Compendio de documentos 1999, Brasilia, January.

(2000a): ¿Qué son los compromisos de gestión?, in R. Lenz and H. Salinas (eds.), Salud pública y economía de la salud para no iniciados. Glosario para las reformas de salud en Latinoamérica, Santiago, Chile.

(2000b): ¿Cómo lograr equidad en las reformas de salud?, in R. Lenz and H. Salinas (eds.), Salud pública y economía de la salud para no iniciados. Glosario para las reformas de salud en Latinoamérica, Santiago, Chile.

Tafani, R. (1997): Reforma al sector salud en Argentina, Financiamiento del desarrollo series, No. 53, Santiago, Chile, ECLAC.

The Economist (2000): A new prescription, London, The Economist Newspaper Limited, 25-31 March.

University of Costa Rica (1998): Estudio de las principales normas de administración del recurso humano de la cCss con base en el ordenamiento jurídico vigente, para determinar su congruencia y forma de adaptación al proceso de modernización institucional, San José, Costa Rica, Fundación de la Universidad de Costa Rica para la Investigación.

Vargas, J.E. and A. Sarmiento (1998): La descentralización de los servicios de educación y salud en Colombia, in E. Di Gropello and R. Cominetti (comps.), La descentralización de la educación y la salud. Un análisis comparativo de la experiencia latinoamericana, Santiago, Chile, ECLAC.

Walsh, K. (1995): Public Services and Market Mechanisms, London, Macmillan Press.

Winchester, D. and S. Bach (1999): Britain. The transformation of public service employment relations, in S. Bach, L. Bordogna, G. Della Rocca and D. Winchester, Public Service Employment Relations in Europe. Transformation, Modernisation or Inertia?, London, Routledge. 